\title{
Forest Ecosystem as a Source of Energy - Biomass Potential of St. Petersburg Region, Russia
}

\author{
Anatoliy Vasil'evich Griazkin \\ St.Petersburg State Forest Technical University, Russia \\ lesovod@bk.ru \\ Natalia Valer'evna Beliaeva \\ galbel06@mail.ru
}

St.Petersburg State Forest Technical University, Russia

\begin{abstract}
Forest ecosystems is an important energy reserve, which accumulates a wealth of alternative fuel. An important feature of this resource - the ability to recover. This paper is dedicated to the study of these features.

This paper reviews the data on dry organic biomass from forest throughout the St. Petersburg region and similar locations in the administrative regions surrounding the St. Petersburg region. Such conifer species as Pinus sylvestris L. (pine) and Pice abies (L.) Karst. (spruce) dominated here.

The investigations were performed in permanent plots in different forest type with stand age more than 90. Under such conditions of forest ecosystems part of carbon in mass of dry wood is 50\%, that is 1:2 (Kobak, 1988; Treyfeld et al., 2003). Potential maximum C stores in forest ecosystems are an important constraint on predictions of the amount of $C$ that can be added to existing $C$ stores. Globally, forest ecosystems offer significant potential to sequester atmospheric $C$ at modest social costs and a wide array of management measures in land-use and forestry have been evaluated for their effectiveness in reducing CO2 concentrations in the atmosphere, however several issues concerning $C$ sequestration in forest ecosystems remain unresolved.

Forest type plays a major role in controlling productivity of forest ecosystems. The authors summarized the data on the identification of common stock of phytomass and carbon in a particular region of Russian Federation (Leningrad region).This article also shows how the ratio of individual biomass components (needles, branches, stems, understory, undergrowth, live ground cover, roots) of the forest ecosystem varied in different forest types. Our reconstruction of maximum potential biomass store applies only to lands currently under forest cover.

If you study the impact of agriculture to the environment in Russia, you cant ignore the forestry. These industries are very close to our environmental conditions.

In the future, forest, as a kind of energy resource will take a more important position than now.
\end{abstract}

Keywords: agricultural and forest systems, source of energy, carbon storage, forest types, environmental safety, Russia, St.Petersburg region, spruce and pine forest stands

\section{INTRODUCTION}

In the absence of stand replacing disturbance, forest ecosystems eventually approach some steady-state carbon $(\mathrm{C})$ stock, which depends on site conditions and properties of plant species. Landscape with entire forest cover in this steady-state condition is presumed to have the highest $\mathrm{C}$ stock that can be sustained over time. Thus we use this landscape condition to define maximum potential $\mathrm{C}$ store.

On the Russia and also the Leningrad region the land covered by forest with more than $50 \%$ so it is important to know the characteristics and dynamics of these ecosystems, including as a source of alternative energy. When considering the energy safety and factors of the stabilizing functions of agriculture we must take into account that in Russian Federation a forest resources are more significant. Since Russia is forest country primarily.

Estimation of potential biomass stores was among the goals of the International Biological Program in the 1970's. This program generated a large set of biomass measurements in plots and many global vegetation 
models rely on these measurements (Albrektson1980; Bazilevich 1993; Griazkin and Garitaselaie 1999; Smirnov and Griazkin 2000; Griazkin 2003; Chertov et al. 2011). At a finer spatial resolution needed for biomass calculations at a regional scale, the potential $\mathrm{C}$ stores are often difficult to assess because in many economically developed forest regions few old-growth forests remain (Yaroshenko et al. 2001). This is due to the long history of conversion of productive forest lands to agriculture and to rotation forestry combined with effects of natural disturbance. Consequently, there are few places both in the St. Petersburg region where ecosystems reached their potential maximum $\mathrm{C}$ storage (Smirnov and Griazkin 2000; Yaroshenko et al. 2001; Smithwick et al. 2002; Griazkin 2003; Chertov et al. 2011).

Potential maximum $\mathrm{C}$ stores in forest ecosystems are an important constraint on predictions of the amount of C that can be added to existing C stores (Jia et al. 2012, Smithwick et al. 2002; Griazkin 2003). Globally, forest ecosystems offer significant potential to sequester atmospheric $\mathrm{C}$ at modest social costs (Kolchugina 1998). A wide array of management measures in land-use and forestry has been evaluated for their effectiveness in reducing $\mathrm{CO}_{2}$ concentrations in the atmosphere (Brown et al. 1996; Smirnov and Griazkin 2000). Several issues concerning $C$ sequestration in forest ecosystems remain unresolved. Many of the existing estimates focus on immediate effects of different management practices (in terms of $\mathrm{kgC} / \mathrm{ha}$ or $\mathrm{kgC} / \mathrm{ha} / \mathrm{yr}$ ) and leave unanswered the critical questions of the timing, security, and sustainability of these effects (Doing 1997, Sampson et al. 2000; Nabuurs et al. 2000). Moreover, these estimates are not explicitly constrained by the carrying capacity of ecosystems (the maximum potential C store) and this may lead to gross over-estimates of $\mathrm{C}$ sequestration in long-term projections into the future.

In the past, late successional forests of the St. Petersburg region and the surrounding area were extensively studied and we used these studies to estimate the maximum potential stores $\mathrm{C}$ in the region (Table 1). To determine the upper bound of $\mathrm{C}$ storage potential in the St. Petersburg region, we first estimated the potential maximum $\mathrm{C}$ store in each of 7 generalized forest types. Then, we calculated the regional total from the distribution of forest areas by these 7 types as reported by forest inventory of 2008 . Finally, we compared the maximum potential C store with the estimated actual C store (Griazkin 2003).

\section{Methodology of THE ReSEARCH}

In this study we treated the St. Petersburg region as a single geographical unit. The terrain of the St. Petersburg region is very flat and there is no pronounced geographical gradient in climatic conditions within the region. Geologically, the Karelian Isthmus can be separated from the rest of the region (see intro and soils chapter for more details), but the data was clearly insufficient to calculate the maximum stores for this province separately. In addition, the small-scale variation in site and drainage conditions influence forest growth far greater than the differences in bedrock or local climate. We used site conditions and primary dominant tree species (or forest types) as the classifiers.

The primary late-successional forests in the St. Petersburg region are commonly dominated by one of the two major conifer species, Pinus sylvestris L. (pine) or Piceaabies (L.) Karst. (spruce). Spruce occurs on sites of medium to high productivity, while pine is the primary species on poor sites, which include dry sandy and rocky soils at one extreme of soil moisture range and poorly drained locations with thick duff or peat layer at the other extreme. Following disturbance, the conifer species are often replaced by the natural regeneration of hardwoods, such as birch (Betula pendula Roth.) and aspen (Populus tremula L.). This process is particularly common on productive sites, where hardwoods have a large competitive advantage as pioneer species.

Forest type classification currently in use by the Russian forest inventory includes 26 forest types. Because it was not feasible to locate a sufficient number of biomass measurements to represent adequately all these types, we simplified the classification and reduced the number of types to 7 generalized ones. These seven types cover the full range of site conditions found in the region and the corresponding range of upper bounds of biomass stores (Zagreev 1992; Griazkin 1999; Surina 2002; Griazkin 2003). In keeping with the Russian forestry tradition, the names of forest types are binary and derived from the Latin name of dominant tree species and the name of an indicator-species that occurs in the ground cover. 
1) Pinetum cladinosum (Pine with white moss) type occupies hilltops and slopes of sandy moraine hills. Most stands are comprised of a single tree species Pinus silvestris L. Understory and undergrowth are usually very sparse or absent. Live ground cover is dominated by lichens, sparse grasses, and Calluna vulgaris (L.) Hull.

2) Pinetum vaccinosum (Pine with Vacciniumvitis-idaea L.) type - occupies well-drained hillsides. Stands are usually comprised of a single tree species Pinus silvestris L. with Juniperus communis L. in the understory. Live ground cover includes Vacciniumvitis-idaea L., Vaccinium myrtillus L., grasses, and mosses (Dicranum polysetum Mich., Dryopteris carthusiana H.P.Euchs.).

3) Piceetum oxalidosum (Spruce with Oxalis acetosella L.) type occupies productive soils of welldrained plains. Stands are mixed with 30 to $90 \%$ of spruce. Understory is represented by Lonicera xylosteum L., Frangula alnus Mill., Sorbus aucuparia L., Rosa acicularis Lindl. Live ground cover is dominated by herbs including Oxalis acetosella L., Majanthenum bifolium F.W.Schmidt, Trientalis europaea L., Convallaria majalis L., Aegopodium podagraria L., Rubus saxatilis L.

4) Piceetum myrtillosum (Spruce with Vaccinium myrtillus L.) type occupies poorly drained plains. Stands are mostly mixed, with 50 to $80 \%$ of spruce and varied proportions of other species (pine, birch and aspen). Understory is represented by Sorbus aucuparia L., Salix caprea L., Frangula alnus Mill. Such species as Vaccinium myrtillus L., Calamagrostis arundinacea Roth., Solidago virgoaurea L., Dryopteris carthusiana H.P.Fuchs, and green mosses are prevailing in live ground cover.

5) Pinetum myrtillosum (Pine with Vaccinium myrtillus L.) type is similar to Piceetum myrtillosum (Spruce with Vaccinium myrtillus L.) type above but is dominated by pine.

6) Pine on wet sites is a generalized type, which includes several diverse forest types on poorly, drained sites, primarily Pinetu mpolytricosum (Pine with Polytricum commune Hedw.) and Pinetum sphagnosum (Pine with sphagnum mosses) types. These types commonly occupy lowlands that remain saturated with stagnant water for a large part of the year. Understory is represented by Salix triandra L. Live ground cover includes Equisetum sylvaticum L., Crepispaludosa L., Polytrichum commune Hedw., and Sphagnum species. In sphagnum types most of live ground cover is represented by Sphagnum spp.

7) Spruce on wet sites is another generalized type, which includes Piceetum herbosum, Piceetum philipendulosum, and some other types that occupy wet sites with flowing ground water in riparian and water springs areas. Stands are often mixed with Salix caprea L., and Alnusincana Moench. in the understory. Live ground cover is represented by Philipendula ulmaria L., Crepispaludosa L., Equisetum sylvaticum L., and Carex globularis L.

For a comprehensive estimate of the total potential biomass in each forest type we searched available publications for all the measured major biomass components including stem wood and bark, tree foliage (needles and leaves), total tree branches (live and dead), roots (fine and coarse, live and dead), forest floor, undergrowth, understory, live ground cover, logs and snags, and mineral soil. However, preliminary examination of data showed that very few publications reported soil $\mathrm{C}$ and detrital pools (snags, $\operatorname{logs}$, forest floor) for the same plots where live biomass components were measured, which made it impossible to calculate meaningful averages for the seven identified forest types. We therefore focused on biomass of live trees and understory vegetation only.

All the information was grouped by forest types described above, including 4 forest types dominated by pine and 3 forest types dominated by spruce (Table 1). The goal was to assemble as complete sample as possible of field biomass measurements for each forest type. We limited our search of published measurements to studies that reported field measurements of at least one major biomass component in addition to the standard measurement of stem wood volume further converted to biomass. The second major selection factor was the age of forest stands: because truly late-successional forests are quite rare in the region and in published studies, we selected biomass measurements for stands that were 90 years or older with no recent disturbances mentioned in plot descriptions.

We attempted to locate sufficient number of measurements for calculation of robust means in all seven forest types. Because the number of measurements for the St. Petersburg region per se was clearly 
insufficient (Smirnov and Griazkin 2000; Griazkin 2003; Chertov et al. 2011), we used measurements from several other regions located in the same broad geographic area as the St. Petersburg region: Arkhangelsk region (Molchanov 1974; Alexeyev Birdsey 1994), Estonia (Kylli and Kyakhrik 1970; Frei et al. 1971; Palumets 1991), Karelia (Scherbakov 1971; Kazimirov et al. 1977), Komi Republic (Bobkova 1987; Alexeyev and Birdsey 1994), Novgorod region (Golovenko et al. 1981; Karpov 1983). In addition, we used three publications where the geographic region was defined only as southern taiga (Alexeyev and Birdsey 1994; Nagimov and Salnikova 1997; Smirnov and Griazkin 2000; Chertov et al. 2011).

Tree biomass measurements followed a standard set of procedures whereby all trees were tallied by diameter classes in plots 0.25 to 1 hectares in size and sample trees were selected from each diameter class (Griazkin 1999; Smirnov and Griazkin 2000; Griazkin 2001). The boles of the selected sample trees were cut into sections for a precise measurement of volume. Other components such as stem, bark, branches, needles and roots were sampled to determine their fractional composition (Utkin 1995; Griazkin 1999, 2001). In some studies (i.e. Alekseev et al. 1973), the more sophisticated methods were used for estimation of root biomass. Soil samples of $19.6 \mathrm{~cm}^{2}$ in area and $20 \mathrm{~cm}$ deep were extracted from transects every 2 meters to obtain information on composition and weight of small roots. For larger roots, the size of soil samples was increased to $336.3 \mathrm{~cm}^{2}$ in area and $100 \mathrm{~cm}$ in depth. To estimate moisture content, samples were first weighed in the field, and then dried at $105{ }^{\circ} \mathrm{C}$ in the laboratory. Dry weights of all components were calculated and an average dry mass per tree was found for each diameter class.

Three types of understory vegetation were included in biomass measurements: undergrowth, which consists of young regeneration of main canopy tree species; understory proper, which is represented by shrubs and small trees (diameter at breast height $<2 \mathrm{~cm}$ ); and live ground cover, which includes herbs, grasses, mosses, lichens, and small shrubs $\left(<0.5 \mathrm{~m}\right.$ high). Sub-plots of $0.25 \mathrm{~m}^{2}$ to $100 \mathrm{~m}^{2}$ in size (Alexeyev et al. 1973; Kazimirov et al. 1977; Griazkin 1999, 2001; 2003) or transects (Alexeyev and Birdsey 1994; Shorohova 2000; Griazkin 2001) were used to sample undergrowth, understory, and live ground cover. Vegetation on sample plots was harvested and weighed by species. If there were many large saplings or shrubs, their biomass was estimated from sample plants (Alexeyev et al. 1973). Roots were measured from soil samples (Kazimirov and Morozova 1973) or estimated from earlier established correlation between above-ground fraction and roots (Kazimirov et al. 1977). Many studies also measured mosses and lichens: Kazimirov and Morozova (1973) used framed plots of $25 \mathrm{~cm}^{2}$ in size and Kannukene (1971) harvested and weighed mosses on square plots of $1 \mathrm{~m}^{2}$ in size.

For each publication included in this analysis, we first compiled data on all reported biomass components and calculated the average biomass for each component. If no data for a certain component was available for a given forest type we used several estimation procedures to fill in the missing data. To substitute for the missing data on understory (all forest types except Piceetum oxalidosum) and undergrowth (Pinetum vaccinosum, Piceetum myrtillosum, and spruce on wet sites), we used the data from Treyfeld (Treyfeld et al., 2003) for mature and older conifer forests: $0.1 \mathrm{~kg} / \mathrm{ha}$ for understory and $2.0 \mathrm{~kg} / \mathrm{ha}$ for undergrowth. In addition, when the measurements of live ground cover were available only for one (pine on wet sites) or two plots (Pinetum cladinosum) we used the measurements in middle-aged stands of the same types. Finally, we summed up estimates for all components in each forest type for an estimate of total potential biomass store (Table 1).

We used forest inventory data for 2008 to determine the distribution of forest lands in the region by the seven forest types defined above. For the regional estimate of maximum potential biomass, all forest lands classified as white moss (Spp. cladinosum) and Spp. Vaccinosum types were assumed to be pinedominated at the late successional stage when the maximum store (as defined in this study) is attained. Similarly, all lands classified as Spp. oxalidosum type were considered spruce-dominated (Piceetum oxalidosum). The proportion of pine-dominated and spruce-dominated forests in the total area of Vaccinium myrtillus and wet forest types (Table 8.2) was used to distribute the areas of these types into pine- and spruce-dominated. The total maximum potential store was calculated using the plot derived averages for the respective forest types and their estimated areas. The part of $\mathrm{C}$ were estimated assuming a biomass of wood to ratio of 1:2. (Kobak 1988; Treyfeld et al. 2003). 
Table11. Mean biomass by dominant species and forest types

\begin{tabular}{|c|c|c|c|c|c|c|}
\hline Forest Type & Live Biom & lass compone & $\mathrm{kg} / \mathrm{ha})$ & & Total & \\
\hline & Stems & $\begin{array}{l}\text { Crowns } \\
\text { (branches, } \\
\text { needles) }\end{array}$ & Roots & $\begin{array}{l}\text { Under- } \\
\text { Story }\end{array}$ & $\begin{array}{l}\text { Live } \\
\text { Biomass } \\
(\mathrm{kg} / \mathrm{ha}) \\
\end{array}$ & Sources \\
\hline Pinetumcladinosum & $\begin{array}{l}0.0001003 \\
(66.5 \%)\end{array}$ & $\begin{array}{l}0.0000228 \\
(15.1 \%)\end{array}$ & $\begin{array}{l}0.0000211 \\
(14.0 \%)\end{array}$ & $\begin{array}{l}0.0000066 \\
(4.4 \%)\end{array}$ & $\begin{array}{l}0.0001508 \\
(100 \%)\end{array}$ & $\begin{array}{l}\text { Molchanov (1974); Molchanov and } \\
\text { Polyakova (1974); Rusanova and } \\
\text { Sloboda (1974); Kazimirov et al. } \\
\text { (1977); }\end{array}$ \\
\hline Pinetumvaccinosum & $\begin{array}{l}0.0001545 \\
(73.5 \%)\end{array}$ & $\begin{array}{l}0.0000207 \\
(9.8 \%)\end{array}$ & $\begin{array}{l}0.0000262 \\
(12.5 \%)\end{array}$ & $\begin{array}{l}0.0000088 \\
(4.2 \%)\end{array}$ & $\begin{array}{l}0.0002102 \\
(100 \%)\end{array}$ & $\begin{array}{l}\text { Molchanov (1974); Molchanov and } \\
\text { Polyakova (1974); Kazimirov et al. } \\
\text { (1977); Griazkin (2003) }\end{array}$ \\
\hline Pinetum myrtillosum & $\begin{array}{l}0.0002249 \\
(74.6 \%)\end{array}$ & \begin{tabular}{|l|}
0.0000293 \\
$(9.7 \%)$
\end{tabular} & $\begin{array}{l}0.0000379 \\
(12.6 \%)\end{array}$ & $\begin{array}{l}0.0000093 \\
(3.1 \%)\end{array}$ & $\begin{array}{l}0.0003014 \\
(100 \%)\end{array}$ & $\begin{array}{l}\text { Molchanov and Polyakova (1974); } \\
\text { Vakurov (1974); Kazimirov et al. } \\
\text { (1977); Romanov and Saevich (1983) }\end{array}$ \\
\hline Pine on wet sites & $\begin{array}{l}0.0000397 \\
(66.3 \%)\end{array}$ & $\begin{array}{l}0.0000089 \\
(14.9 \%)\end{array}$ & $\begin{array}{l}0.000006 \\
(9.9 \%)\end{array}$ & $\begin{array}{l}0.0000053 \\
(8.9 \%)\end{array}$ & $\begin{array}{l}0.0000599 \\
(100 \%)\end{array}$ & $\begin{array}{l}\text { Molchanov and Polyakova (1974); } \\
\text { Kazimirov et al. (1977); Bobkova } \\
\text { (1987); Shorohova 2000; Griazkin } \\
(2003)\end{array}$ \\
\hline Piceetumoxalidosum & $\begin{array}{l}0.0002063 \\
(61.7 \%)\end{array}$ & $\begin{array}{l}0.0000491 \\
(14.7 \%)\end{array}$ & $\begin{array}{l}0.0000744 \\
(22.3 \%)\end{array}$ & $\begin{array}{l}0.0000044 \\
(1.3 \%)\end{array}$ & $\begin{array}{l}0.0003342 \\
(100 \%)\end{array}$ & $\begin{array}{l}\text { Kylli and Kyakhrik (1970); Frei et al. } \\
\text { (1971); Kannukene (1971); Alexeyev } \\
\text { and Berdsy (1994); Ermakov and } \\
\text { Asyutin (1988); Griazkin (1999); } \\
\text { Smirnov and Griazkin (2000) }\end{array}$ \\
\hline Piceetummyrtillosum & $\begin{array}{l}0.000397 \\
(59.2 \%)\end{array}$ & $\begin{array}{l}0.0000468 \\
(19.8 \%)\end{array}$ & $\begin{array}{l}0.0000448 \\
(19.0 \%)\end{array}$ & $\begin{array}{l}0.0000047 \\
(2.0 \%)\end{array}$ & $\begin{array}{l}0.000236 \\
(100 \%)\end{array}$ & 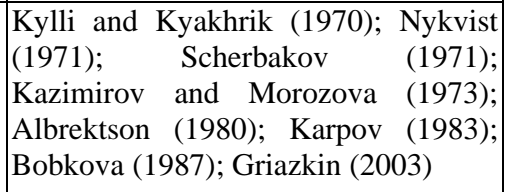 \\
\hline Spruce on wet sites & $\begin{array}{l}0.0000986 \\
(56.6 \%)\end{array}$ & $\begin{array}{l}0.0000353 \\
(20.3 \%)\end{array}$ & $\begin{array}{l}0.0000361 \\
(20.7 \%)\end{array}$ & $\begin{array}{l}0.0000042 \\
(2.4 \%)\end{array}$ & $\begin{array}{l}0.0001742 \\
(100 \%)\end{array}$ & 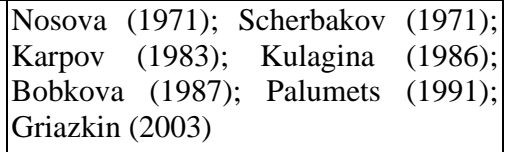 \\
\hline
\end{tabular}

\section{RESUlts}

Survey of the available literature on biomass stores in the forests of the St. Petersburg and nearby regions provided data for the total of 125 plots and the minimum of 8 plots in each of the seven forest types identified in our analysis (Table 1). More information was available for the Vaccinium myrtillus forest type for both pine and spruce, and the least information was found for the wet forest types. The most commonly measured forest components were stem outside bark, live branches, foliage, and roots for all species, which were presented for the majority of the reviewed publications. Less common or absent were measurements of dead biomass components and understory.

Forest type with the highest biomass store was Piceetum oxalidosum $(0.0003342 \mathrm{~kg} / \mathrm{ha})$; for pine the most biomass was reported for Myrtillosum type $(0.0003014 \mathrm{~kg} / \mathrm{ha})$. Pine forests growing in wet conditions stored the least biomass: $0.0000599 \mathrm{~kg} / \mathrm{ha}$. The second-lowest store was also in a pine-dominated type: $0.0001231 \mathrm{~kg} / \mathrm{ha}$ in white moss type. Spruce forests had higher biomass in foliage and roots both in absolute and in relative terms, whereas pine forests had greater biomass in understory, especially in lowproductivity wet and white moss types (Table 1, Figure1). In all forest types except Piceetum oxalidosum the largest understory component was live ground cover $(0.0000021-0.000008 \mathrm{~kg} / \mathrm{ha})$; in Piceetum oxalidosum only $0.0000012 \mathrm{~kg} / \mathrm{ha}$ were in live ground cover but the shrub layer biomass was the highest of all forest types $(0.0000025 \mathrm{~kg} / \mathrm{ha})$.

In all forest types the largest component of the total biomass store was the above-ground tree biomass: from 81 to $84 \%$ in pine stands and from 76 to $79 \%$ in spruce stands (Table 1). Stems of the main canopy 
trees made up between 66 to $75 \%$ in pine and 57 to $62 \%$ in spruce stands. Among pine stands two less productive types (Pinetum cladinosum and Pine on wet sites) had lower proportion of stems in their biomass (66.5 and $66.3 \%$ respectively) than the more productive types (Table 1, Figure 1).

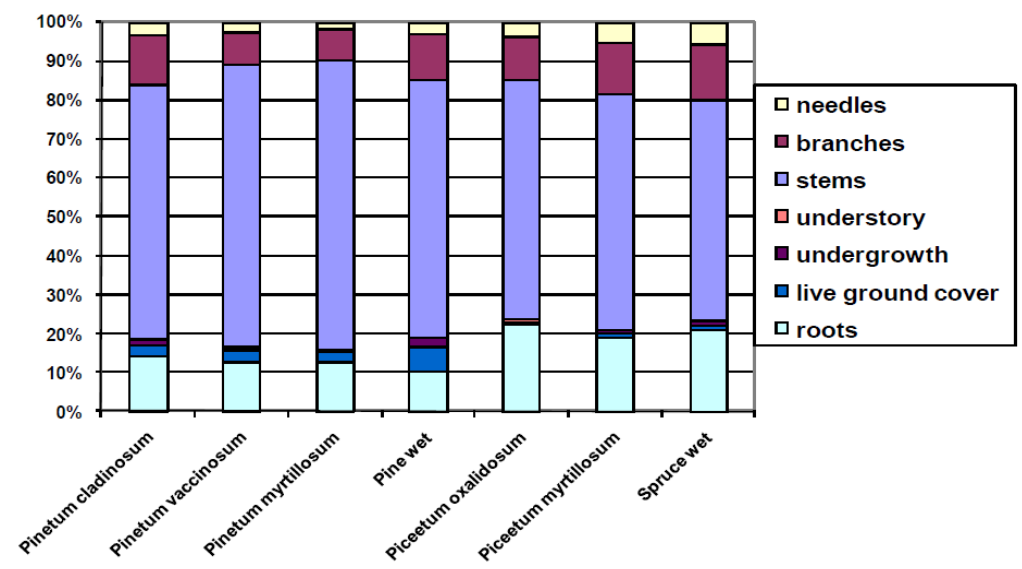

Fig1. Biomass composition in major types of pine and spruce forests of the St. Petersburg region

The forest area currently dominated by pine is greater than area currently dominated by spruce (Table 2). These two species together comprise $59.5 \%$ of all inventoried forest lands; the balance of forests is dominated by hardwoods - mostly birch and aspen. Pine dominates $83 \%$ of all lands in Cladinosum type, $85 \%$ in Vaccinosum type, and $44 \%$ in wet types. In two more productive types (Oxalidosum and Myrtillosum) the proportion of pine forests is relatively low (7\% and $27 \%$ respectively) and the share of spruce is higher (25\% and $41 \%$ respectively). The most productive type, Oxalidosum has the lowest proportion of conifer-dominated stands (32\% only).

Table2. Distribution of pine and spruce forests by area and types (after Strakhov et al. 1999)

\begin{tabular}{|l|l|l|l|l|}
\hline \multirow{2}{*}{ Forest type } & Pine, & Spruce, & \multicolumn{2}{|l|}{ Total (including hardwoods) } \\
\cline { 2 - 5 } & $10^{3}$ ha & $10^{3}$ ha & $\%$ & $10^{3}$ ha \\
\hline Cladinosum & 27.3 & 2.7 & 1 & 32.8 \\
Vaccinosum & 252.1 & 21.8 & 7 & 296.9 \\
Oxalidosum & 65.1 & 226.5 & 21 & 894.9 \\
Myrtillosum & 483.7 & 739.6 & 42 & 1809.4 \\
Polytricosum & 128.3 & 113.8 & 7 & 323.3 \\
Sphagnosum & 451.7 & 19.8 & 12 & 543.6 \\
Philipendulosum & 1.7 & 54.0 & 10 & 449.8 \\
\hline Total & 1409.9 & 1178.2 & 100 & 4351.7 \\
\hline
\end{tabular}

The reconstruction of potential forest cover using the allocation rules adopted in this study changes the balance between pine and spruce (Table 3). In this reconstructed forest cover spruce occupies $66 \%$ of all forest lands, which is $39 \%$ greater than in the actual forest cover in the region, while pine gained only 2 $\%$ of land area. Spruce forests also contain more potential biomass store: $0.0006625 \times 10^{6} \mathrm{~kg}$ or $67 \%$ of the total. The average value of potential biomass store for spruce forests $(0.0002556 \mathrm{~kg} / \mathrm{ha})$ is significantly higher than for pine forests $(0.0001851 \mathrm{~kg} / \mathrm{ha})$.

Table3. Forest area distribution by type and primary dominant tree species used in calculation of total potential biomass

\begin{tabular}{|c|c|c|c|c|c|c|}
\hline \multirow{2}{*}{$\begin{array}{l}\text { Forest } \\
\text { type }\end{array}$} & \multicolumn{2}{|l|}{ Pine } & \multicolumn{2}{|l|}{ Spruce } & \multicolumn{2}{|l|}{ Total } \\
\hline & $\begin{array}{l}\text { Area, } \\
10^{3} \text { ha }\end{array}$ & $\begin{array}{l}\text { Live } \\
\text { Biomass kg/ha }\end{array}$ & $\begin{array}{l}\text { Area, } \\
10^{3} \text { ha }\end{array}$ & $\begin{array}{l}\text { Live } \\
\text { Biomass kg/ha }\end{array}$ & $\begin{array}{l}\text { Area, } \\
10^{3} \text { ha }\end{array}$ & $\begin{array}{l}\text { Biomass, } \\
10^{3} \mathrm{~kg}\end{array}$ \\
\hline Cladinosum & 32.8 & 0.0001508 & - & - & 32.8 & 0.0049462 \\
\hline Vaccinosum & 296.9 & 0.0002102 & - & - & 296.9 & 0.0624084 \\
\hline Oxalidosum & - & - & 894.9 & 0.0003342 & 894.9 & 0.2990756 \\
\hline Myrtillosum & 714.7 & 0.0003014 & 1095.7 & 0.000236 & 1810.4 & 0.4739958 \\
\hline Wet & 714.9 & 0.0000599 & 601.8 & 0.0001742 & 1316.7 & 0.1476561 \\
\hline Total & 1759.3 & & 2592.4 & & 4351.7 & 0.9880821 \\
\hline
\end{tabular}


The greatest forest area and the greatest potential store of biomass is in Myrtillosum type: it makes $42 \%$ of the total area and $48 \%$ of the total potential biomass store (Figure 8.2, Table3). The second most important type in the make-up of the potential biomass store is Oxalidosum: its share in the total store is $30 \%$ even though it only occupies $21 \%$ of the total forest area (Table 2).

The total maximum potential store of organic matter in live vegetation of forests in the St. Petersburg region is $0.0009881 \times 10^{6} \mathrm{~kg}$ (Table3). Using ratio of $\mathrm{C}$ and biomass of wood (1:2), the $\mathrm{C}$ store is estimated at $0.000494 \times 10^{6} \mathrm{~kg} \mathrm{C}$.

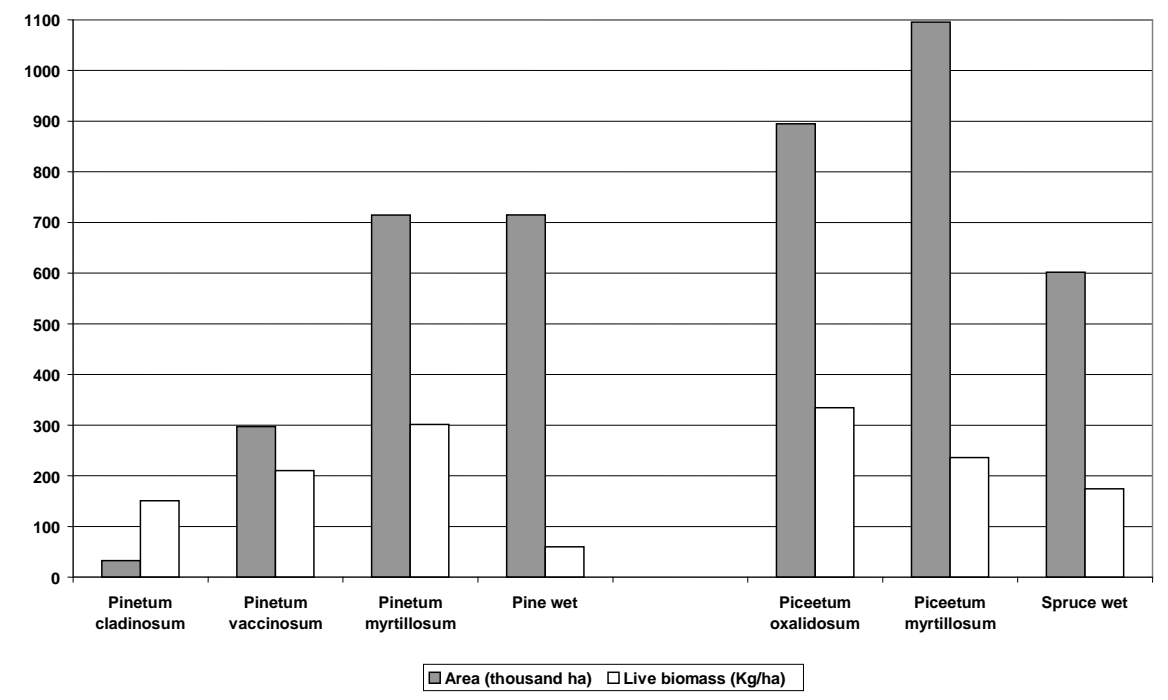

Fig2. Distribution of forests by area and live biomass by forest types

\section{DisCUSSION}

Forests at late stages of succession (over 300 years old) are very rare in Northwestern Russia and especially in the St. Petersburg region (Griazkin 2001; Yaroshenko et al. 2001). Old trees are more common on sites with low productivity, such as poor sandy soils with very deep ground water layer (white moss type) or sphagnum bogs. Few 300-year old pine stands of relatively poor Vaccinosum forest type can be found in the region, however in more productive Mirtyllosum or Oxalidosum forest types on argillaceous (clayey) soils trees rarely reach the age of 300 years (Griazkin 2001). Several factors contribute to this and the most important is clearly the timber harvest. The common harvest age ranges between 50 and 120 years and a large portion of forests reaching that age is harvested. Sites with high productivity are preferred and that is the main reason why it is virtually impossible to find old-growth stands of high productivity. The most fertile soils in the region were converted to agriculture in the past and thus were excluded from our estimate. In addition, the cumulative probability of natural disturbance increases with time since last disturbance. Some disturbance types, such as fires, affect young conifer forests at a higher rate than older ones, while the impact of windstorms for example is greater in older forests. Even though the natural disturbance rate is relatively low in the St. Petersburg region, over time some of the very old forests are lost because of it. Finally, the natural longevity of tree species is relatively low.

The store of biomass in a forest stand increases with age until a certain limit, then it declines as the first generation of trees begins to die. The timing of decline is connected with biological characteristics of tree species, primarily their longevity: the greater the longevity the later maximum biomass is attained (Sokolov et al. 1994). The site type also has an effect on the age when biomass reaches maximum: in Karelia, the maximum aboveground biomass is reported at age 146 in Pinetum vaccinosum and by age 97 in more productive Pinetum myrtillosum (Kazimirov et al. 1977). There is also evidence that spruce stands accumulate biomass faster than pine stands by $20-50$ years. For example, on medium productivity sites spruce stands reach maximum biomass by age 90-100, while pine on these sites reaches maximum biomass by age 130-150 (Vatkovskii 1976). Similarly, in Oxalidosum types maximum biomass was reported at age 50-60 years for spruce and at age 70-90 years for pine (Yakovlev 1982). 
Forest type or site conditions play a major role in controlling productivity of forest ecosystems. The difference between biomass stores in various forest types is nearly 6-fold, ranging from 59.9 (Pine on wet sites) to $0.0003342 \mathrm{~kg} / \mathrm{ha}$ (Piceetum oxalidosum). This is similar to differences in average forest biomass stores in various vegetation zones for Russia as a whole (Figure 3). This indicates that site type can be as important, or even more important than climate in defining forest productivity and biomass stores in a given location.

Biomass data for different forest types is not equally available. In this study we had to pool data for several types to achieve a large enough sample for calculating a meaningful average biomass value. The availability of data for wet types (Polytricosum, Sphagnosum, Philipendulosum) is particularly poor, while moderately productive types are represented much better: we found 26 plots for Piceetum myrtillosum, 21 plots for Piceetum oxalidosum, and 29 plots for Pinetum vaccinosum.

The composition of forest biomass also depends on forest type. In pine forests, bole biomass constitutes between 66 and $75 \%$ of their biomass depending on type, while the proportion of roots and branches varies nearly 2-fold with site type (Table 1). In spruce stands the differences are somewhat smaller.

The composition of biomass in pine-dominated forest types differs from biomass composition of sprucedominated types. In spruce forests, the proportion of stems is lower than in pine forests, while the proportion of leaves and branches is higher. The biomass of lower vegetation layers is also influenced by forest type: in pine-dominated types these layers make up 3.1 to $8.9 \%$ of total biomass, while in sprucedominated types they make 1.3 to $2.4 \%$ of total biomass. The low proportion of biomass found in the lower layers of spruce-dominated forests is explained by the high density of spruce canopy; this reduces light penetration throughout the year and prevents the growth of understory species (Kazimirov et al. 1977; Shorohova 2000; Griazkin 2001).

Our reconstruction of maximum potential biomass store applies only to lands currently under forest cover. It endeavors to eliminate the impact of rotation forestry on regional biomass stores, but not the effect of historical land conversion to agriculture, infrastructure, and urban development. Therefore our results should not be considered as a reconstruction of natural forest cover absent any human impact. Due to the effects of timber harvest and other disturbance, the current $\mathrm{C}$ store in forests of the St. Petersburg region $\left(0.0002075 \times 10^{6} \mathrm{~kg} \mathrm{C}\right.$; Treyfeld et al. 2003; Griazkin 2003) makes only $42 \%$ of the potential store estimated here $\left(0.0004940 \times 10^{6} \mathrm{~kg} \mathrm{C}\right)$.

\section{Conclusion}

In this paper we attempt to assess the potential of carbon stocks in forests of the Leningrad region. The phytomass of the stand was found to increase with age, but for each forest species there is a limit associated with the longevity of a particular tree species. It was revealed that the stock of biomass depends on the type of forest. The most productive types of forest are pine and spruce oxalis and myrtilis forest types. From the study we obtained the data on the ability of spruce stands accumulate biomass faster than pine stands. In Oxalidosum types maximum biomass in spruce forests was found to be accumulated by the age of 50-60 years, and in pine forests - the age of 70-90 years.

The difference between the stock of biomass in different forest types varies up to 6 times: from $59.9 \mathrm{t} / \mathrm{ha}$ of pine forests in the sphagnum to $334.2 \mathrm{t} /$ ha in spruce grove (Piceetum oxalidosum). Approximately there are the same differences and forest zones (see Fig. 3). It means that the forest type is more important than climate in determining the productivity of forests.

The bulk of the forest ecosystems biomass deposited in stems, the share of branches, leaves or needles does not exceed $30-35 \%$. The biomass of the lower layers of vegetation also depends on the forest type. It reaches maximum values (up to $8.9 \%$ of total biomass) in pine forest oxalis type. The mass of roots in forest ecosystems reaches $30 \%$ from all overground phytomass.

The maximum supply of organic matter in the living vegetation of the Leningrad region is 981.8 million tons. 


\section{REFERENCES}

Albrektson A. (1980) Relations between tree biomass fractions and conventional silvicultural measurements. Ecol Bull 32:315-327

Alexeyev V.A., Birdsey R.A. (1994) Carbon in forest and bog ecosystems of Russia. SO RAN, Krasnoyarsk, 208 p. (in Russian) (this is a book)

Alexandros Gasparatos, Per Stromberg, Kazuhiko Takeuchi. 2011. Biofuels, ecosystem services and human wellbeing: Putting biofuels in the ecosystem services narrative.Agriculture, Ecosystems \& Environment, Volume 142, Issues 3-4. Pages 111-128

Alexeyev V.A., Karpov VG, Abrazhko MA (1973) Primary productivity of spruce forests: structure and productivity of spruce forests in south taiga. Nauka, Leningrad, 76-98 p.p. (in Russian) (this is a book)

Bazilevich N.I. (1993) Biological productivity of ecosystems in Northern Eurasia. Nauka, Moscow, 293 p. (in Russian) (this is a book)

Chertov O.G., Gryazkin A.V., Komarov A.S. et. al. (2011) Dynamic modeling in forestry.St. Petersburg State Forest Technical Academy Press, St. Petersburg. 66 p. (this is a book)

Gryazkin A.V. (1999) Structural organization of phytoceonoses of south taiga. St. Petersburg State Forest Technical Academy Press, St. Petersburg (in Russian) (this is a book)

Gryazkin A.V. (2001) Regeneration potential of taiga forests. St. Petersburg State Forest Technical Academy Press, St. Petersburg . 188 p. (inRussian). (this is a book)

Gryazkin A.V., Garitaselaya H.M. (1999) Dynamic model of potassium cycle in forest ecosistems.St. Petersburg State Forest Technical Academy Press, St. Petersburg. 68 p. (this is a book)

Griazkin A.V. (2003) Potential stocks of phytomass in Leningrad region forests. In: Graznov S.E. (ed) Carbon dynamics in forests of Northwest: ecology, economics, politics. St. Petersburg State Forest Technical Academy Press, St. Petersburg, pp 39-42 (in Russian)

Chertov O.G., Gryazkin A.V., Smirnov A.P., Kovalev N.V. (2011) Change of carbon balance and efficiency of a wood land ecosystems at its development in cutting. New sof the St. Petersburg State Forest Technical 197: 127-134.

H. Doing . 1997. The landscape as an ecosystem. Agriculture, Ecosystems \& Environment. Volume 63, Issues 2-3. Pages 221-225

J.X. Jia, Y.C. Ma, Z.Q. Xiong .2012.Net ecosystem carbon budget, net global warming potential and greenhouse gas intensity in intensive vegetable ecosystems in China. Agriculture, Ecosystems \& Environment. Volume 150. Pages 27-37

Karpov V.G. (ed) (1983) Factors regulating ecosystems in spruce forests. Nauka, Leningrad (in Russian)

Kazimirov N.I, Volkov A.D., Zyabchenko S.S., Ivanchikov A.A., Morozova R.M. (1977) Energy and nutrient exchange in pine forests of the European North. Nauka, Leningrad (in Russian)

Kobak K.I. (1988) Biotic components of the carbon cycle. L.:GMI, 247 p.

Kylli P, Kyakhrik P (1970) Phytomass and ash content in Piceetum and Pinetumoxalidosum types of forests. Works of the Estonian Agricultural Academy, Tartu 5:69-91 (in Russian)

Molchanov A.A. (1974) Productivity of organic mass in pine forests of white moss type. In: Molchanov AA (ed) Productivity of organic and biological forest mass. Nauka, Moscow, pp 24-42 (in Russian)

Nabuurs GJ, Dolman AV, Verkaik E, Kuikman PJ, Van Diepen CA, Whitmore A, Daamen W, Oenema O, Kabat P, Mohren GMJ (2000) Article 3.3 and 3.4. of the Kyoto Protocol: consequences for industrialized countries' commitment, the monitoring needs and possible side effect. Environ Sci Policy 3:123-134

Palumets J.K. (1991) Analysis of phytomass partitioning in Norway spruce.ScriptaBotanica 8, Tartu University Press, Tartu

Romanov V.S., Saevich K.F. (1983) Biological productivity of lower plant layers in Pinetum myrtillosum and bog pine forests. LesovedLesnKhoz 18:3-9 (in Russian) 
Saevich K.F. (1988) Above-ground phytomass of the lower plant layers in birch forests of the Pteridium aquilinum type. Botanicheskie Issledovaniya 29:100-102 (in Russian)

Sampson R.N., et al. (2000) Additional Human-induced Activities - Article 3.4. In:

Shorohova E.V. (2000) Carbon dynamics in native spruce forests of the middle

taiga. St. Petersburg State Forest Technical Academy, Autoreferat of

Science Candidate Dissertation (in Russian)

Smirnov A.P., Griazkin A.V. (2000) Organic matter balance and $\mathrm{CO}_{2}$ regime in taiga ecosystems. St. Petersburg State Forest Technical Academy Press, St. Petersburg (in Russian). (this is a book)

Smithwick EAH, Harmon M.E., Remillard SM, Acker SA, Franklin JF (2002) Potential upper bounds of carbon stores in forests of the Pacific Northwest. EcolAppl 12:1303-1317

Sokolov V.A., Atkin A.S., Farber S.K., Atkina L.I. (1994) Structure and dynamics of taiga forests. Nauka, Novosibirsk (in Russian)

Strakhov V.V., Dyakun F.A., Sdobnova V.V., Danilova N.K., Kurdina G.V., Belyakova T.F., Polyakova G.P. (1999) Forest fund of Russia: statistical summary (survey of January 1, 1998). Vsesoyuznyi Nauchno-Issledovatel'skii Informatsionnyi Tsentrpo Lesnym Resursam Goskomlesa SSSR (VNITsLesresurs), Moscow (in Russian)

Tatyana P Kolchugina, Ted S Vinson.1998.Carbon cycle of terrestrial ecosystems of the former Soviet Union. Environmental Science \& Policy. Volume 1, Issue 2, Pages 115-128

Utkin A.I. (1975) Biological productivity of forests. Forestry and forest science, v. 1, All-Russian Institute of Scientific and Technical Information Press, Moscow, 189 p. (in Russian) (this is a book)

Utkin A.I. (1995) Carbon cycle and forestry. forest science 5:3-20 (in Russian)

Zagreev V.V. (1992) All-Union standards on forest mensuration. Kolos, Moscow

(in Russian)

Yaroshenko A.Y., Potapov P.V., Turubanova S.A. (2001) Last intact forest landscapes of Northern European Russia. Greenpeace Russia, Moscow (in Russian) 